大 原 利 章

\section{Toshiaki Ohara}

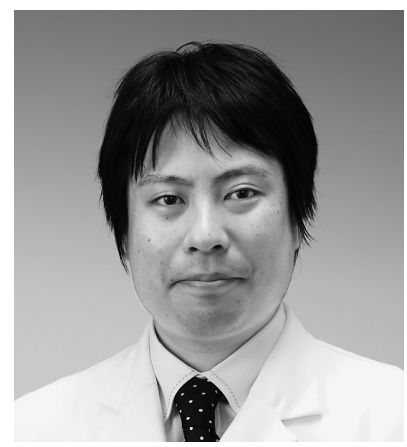

\section{岡山大学大学院医歯学総合研究科 消化器外科学}

Department of Gastroenterological Surgery, Okayama University Graduate School of Medicine, Dentistry and Pharmaceutical Sciences

\section{プロフィール}

昭和52年生まれ

平成14年 3 月 愛媛大学医学部医学科卒業

平成14年 4 月 岡山大学医学部 第一外科学入局

平成14年 7 月 香川労竾病院 外科

平成16年 4 月＼cjkstart岩国医療センター 外科

平成18年 5 月 国立病院機構専修医海外留学第 1 期生として米国へ短期留学

平成23年 9 月 岡山大学大学院医歯薬学総合研究科博士課程修了

平成24年 4 月 岡山大学大学院医歯薬学総合研究科 消化器外科学 非常勤講師

\title{
受賞対象論文
}

Ohara T, Noma K, Urano S, Watanabe S, Nishitani S, Tomono Y, Kimura F, Kagawa S, Shirakawa Y, Fujiwara T : A novel synergistic effect of iron depletion on antiangiogenic cancer therapy. Int J Cancer (2013) 132, 2705-2713.

\section{研究の背景と経緯}

化学療法は進化を重ね，近年では分子標的薬が多く 使われるようになってきた。そのうち血管新生をター ゲットにした血管新生阻害薬は，主要な分子標的薬の ひとつである. 特に bevacizumab は血管新生因子であ るVEGFに対する抗体薬であり, 本邦でも大腸癌, 肺 癌, 卵巣癌等に保険適応が認められ, 多くの症例に使 用されている。一方で分子標的薬は薬剂費が高く医療 費の高騰の問題があり，効率的な使用や技術革新によ る問題の解決が期待されている。

癌と鉄については以前から研究が行われており，様 々な鉄の化合物を踾歯類に投与すると腎癌, 悪性中皮 腫などの悪性腫瘍が誘発されることが知られている11. しかし，逆に鉄を除去（除鉄）する事は動物レベルで 腫瘍の増殖抑制が認められた報告はあるが，一般的な 治療としては確立されていない。我々は腫瘍の増殖に 鉄が必須であり，腫瘍は鉄が不足すると代償的な反応 を起こすという仮説を立て，さらにその反応を逆に利 用すれば治療に応用できるのではないかと考え研究を 行った。

\section{研究成果の内容}

\section{1 、除鉄マウスモデルを用いた皮下腫瘍での検討} 動物体内の鉄分を減らすために，鉄分を除去した食 餌を作成し，3 週間ヌードマウスに投与すると Hb， フェリチン，血清鉄が低下し，体内から鉄分が減少し ていることが確認された。その状態のマウスに肺癌細 胞株 A549を用いて皮下腫瘍を作成し，通常食慨と除 鉄食餌を与え続けると，42日目に除鉄食慨群では有意 に腫瘍の増殖が抑制された。

\section{2.除鉄された腫瘍には代償的血管新生が生じる}

この皮下腫瘍を回収し, 免疫染色とウエスタンブロ ット法によるシグナル解析を行った。除鉄食餌群では 鉄染色で鉄分が認められず，細胞増殖能（Ki67 index） の低下が確認された。さらに低酸素を検出する pimonidazole assay で腫瘍が低酸素化している事が明 らかになり，血管内皮を染める CD31染色を行った所， 微小血管密度の増加が認められた。このことから除鉄 食餌を投与すると腫瘍の増殖が抑制されるが，腫瘍が 低酸素化し，代償的な血管新生が生じていると考えら れた。ウエスタンブロット法によるシグナル解析でも 除鉄食餌群はトランスフェリンレセプター 1 および HIF-1 $\alpha$ を介したVEGF の発現増強が確認された。 


\section{3. 除鉄で誘導を行うと血管新生阻害薬の効果を高め られる}

上記実験の結果から，除鉄状態で血管新生阻害薬を 用いれば高い抗腫瘍効果が期待できると考えられた。 除鉄マウスモデルを用いて血管新生阻害薬 bevacizumab $\left(\right.$ Avastin $\left.^{\circledR}\right)$ との併用効果について検討を行った. 通 常食餌群, 除鉄食餌群, 通常食餌 + bevacizumab 投与 群, 除鉄食慨群 + bevacizumab 投与群の 4 群に分け比 較を行った. 39 日目に除鉄食飭群+ bevacizumab 投与 群では高い抗腫瘍効果が認められた (図). 我々はさら に in vitro でも肺癌細胞株 A549, H1299を用いて, 除 鉄剤として鉄キレート剤（deferasirox）を用いて, 細 胞増殖能および血管新生シグナルについて検討を行っ た。両細胞株に鉄キレート剂を投与すると濃度依存的 に細胞増殖抑制効果が認められ, ELISA 法にて培養液 中の VEGF の濃度を測定すると, 鉄キレート剤の濃度 依存的に VEGF の増加が認められた。さらにウエス夕 ンブロット法で HIF $1-\alpha$ の鉄キレート剂の濃度依存的 なシグナルの増強が確認された。

\section{研究成果の意義}

鉄は生体にとって必須のものであり, それは癌細胞 にとっても同様であり, 鉄が無くなると癌細胞はその


図 除鉄状態で血管新生阻害薬を併用すると強い抗腫瘍効果が認 められた（受賞論文より一部引用）
環境から逃れようとして血管を新生させている事が立 証された。代償的な血管新生のメカニズムについては, in vitro の結果から鉄が不足しているため HIF1ビキチン依存的なプロテアソームによる分解ができな いためと考えられるが, in vivoでは更にへモグロビン 低下による組織低酸素化が寄与して，より強く血管新 生作用が生じているものと推察される。臨床において は，除鉄だけでは癌治療として成立していないが，そ の理由は，上記のメカニズムが働くためであり，この 代償的な血管新生を阻害する事で癌の根治に一歩近づ けられるものと考えられる。

\section{今後の展開や展望}

Bevacizumabは最も頻用されている血管新生阻害 薬であるが，未だに有効なバイオマーカーは発見され ていない。我々の開発した除鉄誘導療法は，鉄関連マ ーカーが血管新生阻害薬の新たなバイオマーカーにな り得る可能性を示している。また, この除鉄誘導療法 は高価な分子標的薬である血管新生阻害薬を効率的に 使用でき，奏効率を高められる可能性があるだけでな く, 副作用の低減にも役立つ事が期待される.

近年動物だけではなく, 臨床での固形癌に対する鉄 キレート療法の可能性についても報告されている2).

今後は前向きの臨床研究を行い, 除鉄誘導療法の確立 を目指すとともにバイオマーカーの有用性についての 検討も準備を進めている。基礎研究については鉄と癌 との関係性についてさらに哚く研究を行い, 発癌から宿 主の終焉にいたる言わば “癌の一生”の過程での鉄が どのように関わっているかを明らかにすることで, 新し い機構の発見や新規治療の開発に結びつけていきたい。

\section{文献}

1) Li JL, Okada S, Hamazaki S, Ebina Y, Midorikawa O : Subacute nephrotoxicity and induction of renal cell carcinoma in mice treated with ferric nitrilotriacetate. Cancer Res (1987) 47, 1867-1869.

2) Yamasaki T, Terai S, Sakaida I : Deferoxamine for advanced hepatocellular carcinoma. N Engl J Med (2011) $365, \quad 576-578$.

平成26年 4 月受理

干700-8558 岡山市北区鹿田町 2-5-1

電話：086-235-7257 FAX : 086-221-8775

E-mail : carib2@msj.biglobe.ne.jp 